\title{
Electronic prescription: frequency and severity of medication errors
}

\author{
(iD) Mário Borges Rosa ${ }^{\mathbf{1}, 2}$ \\ (iD) Mariana Martins Gonzaga do Nascimento ${ }^{1,3}$ \\ (iD) Priscilla Benfica Cirilio ${ }^{4}$ \\ Dosângela de Almeida Santos 4 \\ (iD) Lucas Flores Batista ${ }^{4}$ \\ (iD) Edson Perini ${ }^{3}$ \\ Renato Camargo Couto ${ }^{3}$
}

1. Instituto para Práticas Seguras no Uso de Medicamentos (ISMP-Brasil), Belo Horizonte, MG, Brasil. 2. Fundação Hospitalar do Estado de Minas Gerais, Belo Horizonte, MG, Brasil. 3. Universidade Federal de Minas Gerais, Belo Horizonte, MG, Brasil. 4. Centro Universitário de Belo Horizonte, Belo Horizonte, MG, Brasil.

http://dx.doi.org/10.1590/1806-9282.65.11.1349

\section{SUMMARY}

OBJECTIVE: To assess the frequency and severity of prescriptions errors with potentially dangerous drugs (heparin and potassium chloride for injection concentrate) before and after the introduction of a computerized provider order entry (CPOE) system.

METHODS: This is a retrospective study that compared errors in manual/pre-typed prescriptions in 2007 (Stage 1) with CPOE prescriptions in 2014 (Stage 2) (Total = 1,028 prescriptions), in two high-complexity hospitals of Belo Horizonte, Brasil.

RESULTS: An increase of $25 \%$ in the frequency of errors in Hospital 1 was observed after the intervention ( $p<0.001)$. In contrast, a decreased error frequency of $85 \%$ was observed in Hospital 2 ( $p<0.001)$. Regarding potassium chloride, the error rate remained unchanged in Hospital 1 ( $p>0.05)$. In Hospital 2, a significant decrease was recorded in Stage $2(p<0.001)$. A reduced error severity with heparin $(p<0.001)$ was noted, while potassium chloride-related prescription severity remain unchanged ( $p>0.05)$.

CONCLUSIONS: The frequency and severity of medication errors after the introduction of CPOE was affected differently in the two hospitals, which shows a need for thorough observation when the prescription system is modified. Control of new potential errors introduced and their causes for the adoption of measures to prevent these events must be in place during and after the implementation of this technology.

KEYWORDS: Patient safety. Electronic prescribing. Medication errors. Drug prescriptions.

\section{INTRODUCTION}

A prescription error is a type of error related to writing the prescription itself or an error in the therapeutic decision process. Like any medication error, it has the potential to lead to inappropriate medication use and harm to the patient. Among main prescription errors are illegible writing, use of confusing abbreviations, omission of pharmaceutical form, concentration, administration route, interval, infusion rate, error in drug unit and others ${ }^{\mathbf{1}}$.

In 2011, it was shown that one out of every 854 deaths of hospitalized patients is due to medication errors, which translates into 7,000 deaths per year, and that $72 \%$ of errors are related to prescription. This is underestimated data, given the difficulties of

DATE OF SUBMISSION: 26-Apr-2019

DATE OF ACCEPTANCE: 11-Jun-2019

CORRESPONDING AUTHOR: Mário Borges Rosa

Hospital de Pronto-Socorro João XXIII - Avenida Professor Alfredo Balena, 400

Bairro Santa Efigênia, Belo Horizonte - Minas Gerais, CEP 30130-100

Tel/Fax: +55 (31) 3016-3613

E-mail: mariobr_ca@yahoo.com 
reporting adverse events. In addition, this elevated number evidences the vulnerability of the prescription process ${ }^{2}$.

The computerized prescription process is a complex system that provides the opportunity for standardized and improved communication among health teams. Studies have shown the advantages of electronic prescription systems, such as improving document readability and reducing prescription errors and adverse events, with a positive impact on prescription quality and morbimortality rates ${ }^{3-5}$. Corroborating with this data, in the U.S., estimated annual savings of US\$ 81 billion were achieved in 2005, based on the implementation of the electronic prescribing system (EPS), as well as benefits to patient health and safety, strengthening prevention and improving treatment of chronic diseases ${ }^{6}$.

However, despite data addressing the advantages and benefits of EPS use, a systematic review that evaluated the influence of electronic systems on prescription errors has shown that published studies confirm the reduced frequency of medication errors with the implantation of systems, but the question remains as to whether the severity of adverse events caused by prescription errors is reduced ${ }^{7}$.

Therefore, this study aimed to evaluate the prescribing profile of selected potentially dangerous drugs (PDD) (unfractionated heparin and potassium chloride for injection concentrate) as to the frequency and severity of prescriptions errors before and after implementation of an EPS in two large hospitals of Belo Horizonte, Mina Gerais.

\section{METHODS}

This is an experimental two-stage retrospective study performed in two public teaching hospitals located in the city of Belo Horizonte, Minas Gerais (Hospital 1 and Hospital 2). Both hospitals are large and with closed medical staff and with a total capacity of 956 beds.

\section{Sample}

In Stage 1, manual and pre-typed prescriptions elaborated on 30 consecutive days (from November 17 to December 16, 2007) were analyzed. In Stage 2, electronic prescriptions elaborated on 30 consecutive days (from 01 to 30 September 2014) were also analyzed after the implementation of an EPS without clinical support (which would be a computer-based program that analyze data within EPS to provide prompts and reminders to assist health care providers in implementing evidence-based clinical guidelines at the point of care). The implementation of the EPS occurred simultaneously in 2009 in both hospitals and an extensive training for doctors, pharmacists and nurses was provided by the hospital during that year to guarantee a successful process.

In both stages, we evaluated prescriptions containing at least one of the following PDDs that are associated with a high frequency of errors and significant severity: (1) $10 \%$ potassium chloride (KCl), injectable solution, $10 \mathrm{~mL}$ vial; (2) unfractionated heparin (UFH), injectable solution, $0.25 \mathrm{~mL}$ ampoule with 5,000 IU; or (3) UFH, injectable solution, $5 \mathrm{~mL}$ vial with 5,000 units per $\mathrm{mL}$. Prescriptions with one of the PDDs selected but whose dispensation was not effected by the pharmacy for any reason were rejected, as well as prescriptions of outpatients (serviced only in emergency and outpatient services).

A random number table was used to establish the sample of prescriptions to be analyzed. Three hundred forty-nine Stage 1 prescriptions were compared with 679 Stage 2 prescriptions. The sample for Stage 2 was calculated by accepting an error $\alpha=5 \%$ (0.05), error $\beta=0.20(20 \%)$ and a power of 0.80 (80\%), and with the possibility of detecting a difference of at least $7.5 \%$ among the samples compared.

\section{Study Variables and Data Collection}

Prescriptions were categorized as "pre-typed", "mixed" or "handwritten" (types available in Stage 1) or "electronic" (available in Stage 2).

Prescription errors were identified in the sample of prescriptions evaluated in both stages as to their frequency, type and severity. Dean, Barber and Schachter (2000) criteria were used to identify and classify prescribing errors as to type, which include ${ }^{8}$ :

- A) errors in the decision process: erroneous prescriptions of the pharmaceutical form, concentration, administration route, interval, dose and infusion rate;

- B) errors in the writing of the prescription: (partial or total) illegibility and errors of omission of prescription components. Patient's name, date and information on the body of the prescription - pharmaceutical form, concentration, administration route, interval and PDD name were considered prescription components. 
The PDD dose was classified as a "wrong dose" (when the prescribed dose was 20\% higher or lower than recommended) or as "overdose" (when the prescribed dose was higher than the maximum established by the product's manufacturer or those defined in the literature $)^{9-11}$.

The criteria for judgment of the concentration, administration route, interval and infusion rate were the same as for the pharmaceutical form. The readability of PDDs' names was evaluated and each word was examined separately, trying to avoid interpretation or deduction, according to established standard.

Pharmaceutical form, concentration, administration route, interval and infusion rate were classified as: "wrong" (when the prescription was confronted with references on pharmacology, with the product leaflet and the dictionary of medicinal products, and was incorrect); "Incomplete” (where the pharmaceutical form has not been fully described in the prescription); "Dubious/unclear" (where it was not possible to clearly distinguish the prescribed pharmaceutical form); and "missing" (when the pharmaceutical form was not recorded in the prescription $)^{9-11}$.

PDDs names' readability was also evaluated according to the readability standard and classified as "good readability", "difficult to read" or "illegible". Thus, each word was examined separately, avoiding interpretation or deduction, as per established standard. The Kappa index was used to determine reliability of the readability assessment. Readability was verified by the supervising pharmacist of each hospital and by one more pharmacist independently.

Error severity analysis was based on index 1 to 6 proposed by the National Coordinating Council for Medication Error Reporting and Prevention (NCC MERP) ${ }^{12}$ modified by Forrey et al. ${ }^{13}$ : (1) no error; (2) an error that would not reach the patient; (3) an error without harm but that could reach the patient and requires monitoring to avoid harm; (4) an error that could lead to temporary harm; (5) an error that could lead to permanent harm; (6) an error that could lead to death.

The prescription error (at least one error or some type of prescription error) was defined as a dependent variable. We considered hospitals (1 or 2 ) or study stage (1 or 2 ) as independent variables.

\section{Data review}

A univariate analysis was performed to evaluate differences between the two hospitals and between the two stages. We used the chi-square test for this study, or the Fisher-Freeman-Halton test for frequencies lower than five. The Kruskal-Wallis test was used for the comparison between hospitals and stages. All the results were significant for a probability of significance of less than 5\% ( $\mathrm{p}<0.05)$. Statistical Package for Social Sciences (SPSS) software version 17.0 was used for all analyses.

\section{Ethical Aspects}

The proposed research was registered in the National Health System and National Commission of Ethics in Research (SISNEP/CONEP) under $\mathrm{N}^{\circ}$ 0028.1.191.000-05 and was approved by the Research Ethics Commissions / Committees of the two hospitals participating in the project.

\section{RESULTS}

\section{Errors Involving Unfractionated Heparin}

During Stage 2 at Hospital 1, there was a statistically significant increase in the frequency of prescriptions with at least one error and in the number of pharmaceutical form errors, and the first variable was directly affected by the increase of the second one. On the other hand, a reduced number of errors involving the concentration and dose of UFH was detected. In Hospital 2, there was a statistically significant reduction in the frequency of all variables, except errors associated with the administration route (Table 1).

\section{Errors Involving Potassium Chloride}

Regarding potassium chloride (Table 2), we observed a statistical relevance for the variables: some error, pharmaceutical form and drug administration route. In Hospital 1, the frequency of errors remained unchanged ( $p>0.001)$ regardless of stages for the variables some error and pharmaceutical form, and there was an increase of $46.5 \%(\mathrm{p}<0.001)$ in the error frequency of the drug administration route. In Hospital 2, there was a statistically significant reduction of errors for the three variables in Stage 2.

\section{Error Severity Assessment}

By analyzing the most frequent types of prescriptions of UFH errors (errors associated with the pharmaceutical form and concentration), a significant reduction of its severity rate was observed after the implementation of the EPS. Regarding errors observed in the prescription of $\mathrm{KCl}$, no statistically significant changes were identified in its severity profile (Table 3 ). 
TABLE 1. COMPARATIVE ANALYSIS BETWEEN HOSPITALS AND STAGES REGARDING TYPES OF ERRORS OBSERVED IN THE PRESCRIPTIONS OF UNFRACTIONATED HEPARIN

\begin{tabular}{|c|c|c|c|c|}
\hline \multirow[t]{2}{*}{ Type of Error } & \multirow[t]{2}{*}{ Stage } & \multicolumn{2}{|c|}{$\begin{array}{l}\text { Error Frequency } \\
\text { Number of prescriptions with errors/ } \\
\text { Total number of prescriptions (\%) }\end{array}$} & \multirow[t]{2}{*}{ p-value } \\
\hline & & Hospital 1 & Hospital 2 & \\
\hline \multirow{3}{*}{ Prescription with at least one error } & 1 & 156/203 (76.8) & 141/146 (96.6) & $<0.001$ \\
\hline & 2 & $352 / 352(100)$ & 6/327 (1.8) & $<0.001$ \\
\hline & p-value & $<0.001$ & $<0.001$ & \\
\hline \multirow{3}{*}{ Pharmaceutical form } & 1 & 148/203 (72.9) & $129 / 146(88.4)$ & $<0.001$ \\
\hline & 2 & $352 / 352(100)$ & $6 / 327(1.8)$ & $<0.001$ \\
\hline & $p$-value & $<0.001$ & $<0.001$ & \\
\hline \multirow{3}{*}{ Concentration } & 1 & $91 / 203(44.8)$ & $107 / 146(73.3)$ & $<0.001$ \\
\hline & 2 & $90 / 352(25.6)$ & 6/327 (1.8) & $<0.001$ \\
\hline & p-value & $<0.001$ & $<0.001$ & \\
\hline \multirow{3}{*}{ Administration route } & 1 & $0 / 203(0.0)$ & $2 / 146(1.4)$ & 0.174 \\
\hline & 2 & $3 / 352(0.9)$ & $3 / 327(0.9)$ & 1.000 \\
\hline & $p$-value & 0.303 & 0.646 & \\
\hline \multirow{3}{*}{ Administration interval } & 1 & $0 / 203(0.0)$ & $4 / 146(2.7)$ & 0.003 \\
\hline & 2 & $0 / 352(0.0)$ & $0 / 327(0.0)$ & - \\
\hline & $p$-value & - & 0.009 & \\
\hline \multirow{3}{*}{ Dose } & 1 & $59 / 203(29.1)$ & $59 / 146(40.4)$ & 0.027 \\
\hline & 2 & $0 / 352(0.0)$ & $0 / 327(0.0)$ & - \\
\hline & p-value & $<0.001$ & $<0.001$ & \\
\hline
\end{tabular}

TABLE 2. COMPARATIVE ANALYSIS BETWEEN HOSPITALS AND STAGES REGARDING TYPES OF ERRORS OBSERVED IN THE PRESCRIPTIONS OF POTASSIUM CHLORIDE FOR INJECTION CONCENTRATE

\begin{tabular}{|c|c|c|c|c|}
\hline \multirow[t]{2}{*}{ Type of Error } & \multirow[t]{2}{*}{ Stage } & \multicolumn{2}{|c|}{$\begin{array}{l}\text { Error Frequency } \\
\text { Number of prescriptions with errors/ } \\
\text { Total number of prescriptions (\%) }\end{array}$} & \multirow[t]{2}{*}{$p$-value } \\
\hline & & Hospital 1 & Hospital 2 & \\
\hline \multirow{3}{*}{ Prescription with at least one error } & 1 & 65/65 (100) & $45 / 45(100)$ & - \\
\hline & 2 & $91 / 91(100)$ & $18 / 85(21.2)$ & $<0.001$ \\
\hline & p-value & - & $<0.001$ & \\
\hline \multirow{3}{*}{ Pharmaceutical form } & 1 & 65/65 (100) & $42 / 45$ (93.3) & 0.066 \\
\hline & 2 & 91/91 (100) & $1 / 85(1.8)$ & $<0.001$ \\
\hline & p-value & - & $<0.001$ & \\
\hline \multirow{3}{*}{ Concentration } & 1 & $4 / 65(6.2)$ & $6 / 45(13.3)$ & 0.312 \\
\hline & 2 & $0 / 91(0.0)$ & $0 / 85(0.0)$ & - \\
\hline & p-value & 0.029 & 0.001 & \\
\hline \multirow{3}{*}{ Administration route } & 1 & $35 / 65$ (53.8) & $41 / 45(91.1)$ & $<0.001$ \\
\hline & 2 & $91 / 91(100)$ & $1 / 85(1.2)$ & $<0.001$ \\
\hline & p-value & $<0.001$ & $<0.001$ & \\
\hline \multirow{3}{*}{ Administration interval } & 1 & $0 / 65(0.0)$ & $2 / 45(4.4)$ & 0.165 \\
\hline & 2 & $0 / 91(0.0)$ & $3 / 85(3.5)$ & 0.111 \\
\hline & p-value & - & 1.000 & \\
\hline \multirow{3}{*}{ Dose } & 1 & 21/65 (32.3) & $9 / 45$ (20.0) & 0.154 \\
\hline & 2 & $0 / 91(0.0)$ & $0 / 85(0.0)$ & - \\
\hline & p-value & $<0.001$ & $<0.001$ & \\
\hline
\end{tabular}




\section{DISCUSSION}

Prescription errors are cited as one of the most common types of errors. While this is an alarming fact, international and national studies indicate that these are the most likely to be adapted to increase the safety of hospitalized patients ${ }^{14}$.

Such errors were very much the case in Stage 1 prescriptions in both hospitals because non-standard manual prescriptions were used. Despite the high initial frequency of errors in both hospitals, the introduction of EPS brought divergent results for the two analyzed institutions, since there was an increased frequency of errors in Hospital 1 and reduced frequency in Hospital 2.

In Hospital 2, most of Stage 1 prescriptions contained considerable writing errors (e.g. data omission, illegibility and use of dangerous abbreviations) that were easily corrected after implementation of an EPS with appropriate parameterization containing drug name, pharmaceutical form, presentation, posology and administration route. Thus, the EPS contributed directly to reduced frequency of errors involving UFH and $\mathrm{KCl}$.

The increased overall error frequency in Hospital 1 and in the errors involving the pharmaceutical form of UFH and $\mathrm{KCl}$ and in the administration route errors for $\mathrm{KCl}$ can be explained by the implementation of a system with inadequate parameterization of the prescription that did not take into account issues that are important to prescription safety, such as permission to use dangerous abbreviations, lack of automatic filling of standardized items (e.g. pharmaceutical form), permission of incorrect dosage and administration route prescriptions.
In the specific case of $\mathrm{KCl}$ in Hospital 1, the missing drug form in the EPS caused systematically repeated errors every time the drug was prescribed. Therefore, $100 \%$ of the prescriptions had some error. In the prescription of UFH in both hospitals, the most frequent types of initial errors were of pharmaceutical form that were associated with the availability of two presentations of this medicine in both institutions. On the one hand, the adequate parameterization of UFH presentations in the EPS of Hospital 2 allowed a reduced frequency of errors in the mentioned variables. In Hospital 1, whose EPS allowed each prescriber to parameterize his prescription individually, incorrect pharmaceutical form errors increased.

In spite of EPS's advantages over manual prescription, this study corroborates with the international literature that shows the EPS' potential to increase the number of errors and adverse events during the first years after its implantation, since its creation can evidence failures that are detected and corrected only after a given period ${ }^{6,15,16}$. In this perspective, patient safety experts health professionals must be directly involved in the development and adequacy of the EPS with a view to designing systems that are safer and more efficient ${ }^{15}$.

Analysis of error severity showed a statistically significant reduction in the frequency of severe errors (category 4) with UFH ( $<<0.001)$, which was mainly due to the fact that prescriptions were more complete and organized in Stage 2, reducing errors associated with the pharmaceutical form of this medicinal product. This fact contradicts what has been detected in other international studies ${ }^{16}$ and is extremely relevant, since this type of error has the potential of a

TABLE 3. COMPARATIVE ANALYSIS BETWEEN HOSPITALS AND BETWEEN STAGES REGARDING THE SEVERITY OF ERRORS OBSERVED IN THE PRESCRIPTIONS OF UNFRACTIONATED HEPARIN AND POTASSIUM CHLORIDE FOR INJECTION CONCENTRATE BY STUDY STAGE

\begin{tabular}{|c|c|c|c|c|c|c|}
\hline & \multirow[t]{2}{*}{ Type of Error } & \multirow[t]{2}{*}{ Stage } & \multicolumn{3}{|c|}{$\begin{array}{l}\text { Severity } \\
\text { Number of prescriptions with errors (\%) }\end{array}$} & \multirow[t]{2}{*}{$\mathrm{p}$-value } \\
\hline & & & 1 & 2 & 4 & \\
\hline \multirow{4}{*}{ Heparin } & \multirow{2}{*}{ Pharmaceutical form } & 1 & $1(0.7)$ & $122(83.0)$ & $24(16.3)$ & \multirow{2}{*}{$<0.001$} \\
\hline & & 2 & $\mathrm{O}(0.0)$ & $351(100)$ & $\mathrm{O}(0.0)$ & \\
\hline & \multirow{2}{*}{ Concentration } & 1 & $1(1.1)$ & $65(72.2)$ & $24(26.7)$ & \multirow{2}{*}{$<0.001$} \\
\hline & & 2 & $1(1.1)$ & $89(98.9)$ & $\mathrm{O}(0.0)$ & \\
\hline \multirow{4}{*}{$\begin{array}{l}\text { Potassium } \\
\text { Chloride }\end{array}$} & \multirow{2}{*}{ Pharmaceutical form } & 1 & $1(1.6)$ & $62(96.8)$ & $1(1.6)$ & \multirow{2}{*}{0.169} \\
\hline & & 2 & $\mathrm{O}(0.0)$ & $91(100)$ & $\mathrm{O}(0.0)$ & \\
\hline & \multirow{2}{*}{ Administration route } & 1 & $2(6.7)$ & $27(90.0)$ & $1(3.3)$ & \multirow{2}{*}{0.222} \\
\hline & & 2 & $3(3.3)$ & $88(96.7)$ & $\mathrm{O}(0.0)$ & \\
\hline
\end{tabular}


wrong choice among UFH presentations available at the institution. Thus, since the injectable solution of the ampoule is four times more concentrated than the vial solution and considering the high frequency of prescription of this drug in the hospital environment, the wrong choice between the two presentations due to drug prescription failure can lead to defining errors in health and adverse events, such as thromboembolic or hemorrhagic events that may contribute to the worsening of the general state of the patient and even his death ${ }^{17}$.

In the KCl prescriptions, no statistically significant differences were detected in the severity of errors with the advent of EPS. However, it should be noted that, in manual prescriptions, many errors were gross with prominence for the readability of prescriptions, subject to different interpretations and, therefore, errors were potentially more serious. On the other hand, regarding typed prescriptions, errors were serial, systematic and repetitive due to failures in the system itself, leading to an increased number of errors. In addition, data such as patient information and readability of prescriber's signature were found in almost $100 \%$ of electronic prescriptions. This result evidences that, although electronic prescription minimizes interpretation errors caused by illegible or similar spelling of the nomenclature of pharmacological compounds, care should be taken to avoid technical errors ${ }^{6,18}$.

Some studies have already shown that EPS promote benefits in patient health and safety. The importance of reducing the frequency of prescription errors is also related to lower unnecessary expenses due to correction and prevention of incidents and adverse events that can, for example, prolong hospital stay and require additional examinations. We emphasize that an unreadable prescription usually requires contacting the prescriber for content elucidation and can extend the length of the medication process. These are direct and indirect costs that are borne by the institution and increase the total costs of health care ${ }^{17,19,20}$.

\section{CONCLUSIONS}

The implementation of EPS has improved the prescription process when one considers the organization and readability of prescriptions as contributing factors in reducing error frequency. The full parameterization of prescriptions was instrumental to the achievement of these results, since, there was a statistically significant decline in the overall frequency and specific types of errors in the hospital where drug description in the computerized system was complete.

The severity of medication errors after the introduction of EPS was affected differently in both hospitals, evidencing the need for careful observation when the prescription system is created and implemented. Therefore, it should be noted that control must be exerted over potential new errors introduced and their causes for the adoption of measures for their prevention during and after the implementation of this technology.

\section{RESUMO}

OBJETIVO: Avaliar a frequência e a gravidade de erros em prescrições envolvendo medicamentos potencialmente perigosos (heparina e cloreto de potássio concentrado injetável) antes e após a introdução de um sistema de prescrição eletrônica.

MÉTODOS: Trata-se de estudo retrospectivo que comparou erros em prescrições manuais e pré-digitadas de 2007 (Fase 1) com prescrições eletrônicas de 2014 (Fase 2) (total = 1.028 prescrições), em dois hospitais de alta complexidade de Belo Horizonte.

RESULTADOS: Foi observado no hospital 1 aumento de $25 \%$ dos erros depois da intervenção ( $p<0,001)$, e no hospital 2 foi verificada redução de 85\% ( $p<0,001$ ). Para o cloreto de potássio, a frequência de erros permaneceu a mesma no hospital 1 ( $p>0,05)$, independentemente da fase e, no hospital 2, ocorreu redução significativa na fase $2(p<0,001)$. Foi identificada redução da gravidade dos erros com a heparina $(p<0,001)$, mas não houve alteração na gravidade dos erros com cloreto de potássio $(p>0,05)$.

CONCLUSÕES: A frequência e a gravidade dos erros de medicação após a introdução de prescrição eletrônica foram impactadas de forma diferente nos dois hospitais, demonstrando necessidade de observação criteriosa quando o sistema de prescrição é modificado. Durante e após a implantação dessa tecnologia, deve existir controle dos novos erros potenciais introduzidos e suas causas para a adoção de medidas de prevenção desses eventos.

PALAVRAS-CHAVE: Segurança do paciente. Prescrição eletrônica. Erros de medicação. Prescrições de medicamentos. 


\section{REFERENCES}

1. Brasil. Ministério da Saúde, ANVISA, FIOCRUZ, FHEMIG. Protocolo de segurança na prescrição, uso e administração de medicamentos. 2014. 45 p. [cited 2016 Oct 4] Available from: http://www20. anvisa.gov.br/segurancadopaciente/index.php/publicacoes/item/ seguranca-na-prescricao-uso-e-administracao-de-medicamentos.

2. Treviño-Montes DO, Villarreal-Alarcón MA, Martínez-Canseco EB, Rodríguez-Gutiérrez R, Baena-Trejo IL, Galarza-Delgado DA. Acontecimientos adversos por medicamentos en pacientes médicos hospitalizados. Medicina Universitaria. 2011;13(51):84-90.

3. Phillips JL, Shea JM, Leung V, MacDonald D. Impact of early electronic prescribing on pharmacists' clarification calls in four community pharmacies located in St John's, Newfoundland. JMIR Med Inform. 2015;3(1):e2.

4. Alanazi MA, Tully MP, Lewis PJ. A systematic review of the prevalence and incidence of prescribing errors with high-risk medicines in hospitals. J Clin Pharm Ther. 2016;41(3):239-45.

5. Nuckols TK, Smith-Spangler C, Morton SC, Asch SM, Patel VM, Anderson $L$ J, et al. The effectiveness of computerized order entry at reducing preventable adverse drug events and medication errors in hospital settings: a systematic review and meta-analysis. Syst Rev. 2014;3:56.

6. Hinojosa-Amaya JM, Rodríguez-García FG, Yeverino-Castro SG, Sánchez-Cárdenas M, Villarreal-Alarcón MA, Galarza-Delgado DA. Medication errors: electronic vs. paper-based prescribing. Experience at a tertiary care university hospital. J Eval Clin Pract. 2016;22(5):751-4.

7. Radley DC, Wasserman MR, Olsho LE, Shoemaker SJ, Spranca MD, Bradshaw B. Reduction in medication errors in hospitals due to adoption of computerized provider order entry systems. J Am Med Inform Assoc. 2013;20(3):470-6.

8. Dean B, Barber N, Schachter M. What is a prescribing error? Qual Health Care. 2000;9(4):232-7.

9. American Society of Health-System Pharmacists. ASHP: drug information. Bethesda: ASHP; 2013.

10. Dicionário de especialidades farmacêuticas. $33^{\mathrm{a}}$ ed. Rio de Janeiro: EPUC; 2012/2013.
11. Fuchs FD, Wannmacher $L$, Ferreira MBC. Farmacologia clínica: fundamentos da terapêutica racional. $4^{a}$ ed. Rio de Janeiro: Guanabara Koogan; 1261 p. 2010.

12. National Coordinating Council for Medication Error Reporting and Prevention. NCC MERP index for categorizing medication errors. 2001. [Cited 2016 Oct 12]. Available from: http://www.nccmerp.org/sites/default/files/ indexColor2001-06-12.pdf.

13. Forrey RA, Pedersen CA, Schneider PI. Interrater agreement with a standard scheme for classifying medication errors. Am J Health Syst Pharm. 2007;64(2):175-81.

14. Slight SP, Howard R, Ghaleb M, Barber N, Franklin BD, Avery AJ. The causes of prescribing errors in English general practices: a qualitative study. $\mathrm{Br}$ Gen Pract. 2013;63(615):e713-20.

15. American Society of Health-System Pharmacists. Landmines and pitfalls of computerized prescriber order entry. [cited 2016 Oct 12]. Available from: http://www.ashp.org/menu/PracticePolicy/ResourceCenters/ PatientSafety/Landmines-and-Pitfalls.aspx

16. Schiff GD, Amato MG, Eguale T, Boehne IJ, Wright A, Koppel R, et al. Computerized physician order entry-related medication errors: analysis of reported errors and vulnerability testing of current systems. BM| Qual Saf. 2015;24(4):264-71.

17. Smeulers M, Verweij L, Maaskant IM, Boer M, Krediet CT, Nieveen van Dijkum EJ, et al. Quality indicators for safe medication preparation and administration: a systematic review. PLoS One. 2015;10(4):e0122695.

18. Benetoli J, Baron AF, Sangalli R, Bianchini OM, Bian VMC, Ferreira Neto CJB. Abreviaturas perigosas e descrições inadequadas de dose em prescrições de medicamentos. Rev Bras Farm Hosp Serv Saúde. 2011;2(1):10-4.

19. Aguiar G, Silva Junior LA, Ferreira MAM. Ilegibilidade e ausência de informação nas prescrições médicas: fatores de risco relacionados a erros de medicação. Rev Bras Prom Saúde. 2006;19(2):84-91.

20. Bhosale MS, Jadhav NB, Adhav CV. Analysis of completeness and legibility of prescription orders at a tertiary care hospital. Int J Med Public Health. 2013;3(3):180-3. 